Економічні науки: збірник наукових прачь Луиького національного технічного університету. Серія "Регіональна економіка". Випуск 17 (67). Редкол.: відп. ред. к.е.н., професор І.В. Кривов’язюк. Луцьк: ІВВ Луцького НТУ, 2020. 348 с.

УДК 336.74

Вісина Т.М., к.і.н., доцент

Вісин В.В., д.і.н., професор

Полянська Т.О., асистент кафедри МЕВ

Луцький національний технічний університет

\title{
ТЕОРЕТИЧНІ ОСНОВИ ВАЛЮТНИХ КРИЗ
}

У науковій статті проведено дослідження підходів до трактування поняття «валютна криза». Розглянута еволюція економічної природи валютних криз та дана їм класифікація.

Ключові слова: валютна криза, фінансова криза, платіжний баланс, золотомонетний стандарт, Бреттон-Вудська валютна система, Ямайська валютна система.

\section{Visyna T., Visyn V., Polianska T. THEORETICAL FOUNDATIONS OF CURRENCY CRISES}

The global financial and economic crisis of 2008-2009, which originated in the United States, spread to most countries and affected all levels of economies: national, regional and global. The crisis took place in conditions of strong interdependence between financial and real sectors of the economy, revealed new features in the nature of crisis phenomena and identified a number of problems that require further analysis, including the economic nature of the currency crisis as part of the financial crisis.

The crisis of the national currency is expressed in a sharp significant devaluation (devaluation) of the national currency for a relatively short period of time (from several days to several months) after a period of relative stability of the exchange rate.

The crisis of the single currency as an artificial entity based on the agreement of the member states of the monetary union arises as a result of a low degree of economic integration and contradictions in the implementation of a single monetary and fiscal policy for countries with different public finances. single currency and the collapse of the monetary union.

The crisis of the world reserve currency is a crisis of the foundations of the current world monetary system, which leads to rethinking and developing the principles of the new world monetary system, which lasts for a long time due to the need for coordination and support of most leading world powers. economic processes and changes in the balance of power in the world economy.

Key words: currency crisis, financial crisis, balance of payments, gold coin standard, Bretton Woods currency system, Jamaican currency system. 
Економічні науки: збірник наукових прачь Луиького національного технічного університету. Серія "Регіональна економіка". Випуск 17 (67). Редкол.: відп. ред. к.е.н., професор І.В. Кривов’язюк. Луцьк: ІВВ Луцького НТУ, 2020. 348 с.

Висына Т., Висын В., Полянская Т.

\section{ТЕОРЕТИЧЕСКИЕ ОСНОВЫ ВАЛЮТНЫХ КРИЗИСОВ}

В научной статье проведено исследование подходов к трактовке понятия «валютный кризис». Рассмотрена эволюция экономической природы валютных кризисов и данная им классификация.

Ключевые слова: валютный кризис, финансовый кризис, платежный баланс, золотомонетный стандарт, Бреттон-Вудская валютная система, Ямайская валютная система.

Постановка проблеми у загальному вигляді та її зв'язок з важливими науковими і практичними завданнями. Світова фінансово-економічна криза 2008-2009 pp., що зародилася у США, поширилась на більшість країн і зачепила всі рівні економік: національні, регіональні та світові. Криза протікала в умовах сильної взаємозалежності між фінансовими i реальними секторами економіки, виявила нові риси в природі кризових явищ i позначила ряд проблем, як вимагають подальшого аналізу, серед них економічна природа валютної кризи як складової частини фінансової кризи.

У науці відсутній єдиний підхід до трактування поняття валютної кризи. На різних етапах розвитку економічної теорії були запропоновані різні класифікації валютних криз, а також розроблені моделі механізму їх протікання. В сучасних умовах деякі аспекти теорії валютних криз необхідно систематизувати $і$ доповнити.

\section{Аналіз останніх досліджень у яких започатковано вирішення проблеми.}

Теоретичним питанням i емпіричному дослідженню валютних криз присвячена велика кількість як українських, так i зарубіжних монографій, наукових статей, аналітичних матеріалів.

Західні дослідники внесли значний вклад в систематизацію і розробку теорії валютних криз, ними були запропоновані моделі поколінь валютних криз. Першу лінійну модель валютної кризи створив П. Кругман в 1979 р Надалі 
Економічні науки: збірник наукових прачь Луиького національного технічного університету. Серія "Регіональна економіка". Випуск 17 (67). Редкол.: відп. ред. к.е.н., професор І.В. Кривов'язюк. Луиьк: ІВВ Луцького НТУ, 2020. 348 с.

розробку моделей продовжили А. Веласко, П. Гарбер, М. Обстфельд, Р. Флуд, Дж. Френкел, Р. Чанг і ін. У 1990-і роки виник окремий напрямок вивчення проблеми - міжнародне поширення криз. Дослідженнями даного питання займалися Б. Айхенгрин, Ч. Выплош, Р. Дорнбуш, Г. Камински, К. Рейнхард, А. Роуз та ін.

Напрями реформування світової валютної системи розроблялися Л. Мізеса, П. Самуельсоном, Р. Триффін, М. Фрідманом, Ф. Хайєк, Е. Хансеном. Аналізу оптимальних валютних зон присвячені роботи Дж. Інграма, П. Кенена, Р. Маккиннона, Р. Манделла, Дж.М. Флемінга. Світова фінансово-економічна криза 2008-2009 pp. змусив переосмислити підходи до проблеми валютних криз. Економічну природу світової фінансово-економічної кризи досліджували А.В. Бузгалин, Р.С. Грінберг, А.І. Колганов, А.А. Пороховский, М.А. Сажина, Г.Г. Чибриков.

Цілі статті. Аналіз теоретичного підходу до трактування поняття «валютна криза», еволюція їх економічної природи та класифікація валютних криз.

Виклад основного матеріалу дослідження 3 повним обгрунтуванням отриманих наукових результатів. В українських і закордонних наукових дослідженнях відсутній єдиний підхід до трактування поняття «валютна криза».

Так, на думку А.В. Анікіна, валютна криза є частиною фінансової кризи і має специфічні ознаки. Валютна криза проявляється в погіршенні платіжного балансу по поточних операціях, догляді капіталу і дефіциту платіжного балансу за капітальними операціями, виснаженні валютних резервів, різкому зниженні курсу національної валюти, введення або посилення валютних обмежень [1].

Л.Н. Красавіна використовує більш широкий науковий підхід і розглядає валютну кризу, перш за все, як кризу світової валютної системи, характеризує його через вибух валютних протиріч, різке порушення функціонування валютної системи, що виявляється в невідповідності структурних принципів організації міжнародних валютних відносин до нових умов 
Економічні науки: збірник наукових прачь Луиького національного технічного університету. Серія "Регіональна економіка". Випуск 17 (67). Редкол.: відп. ред. к.е.н., професор І.В. Кривов'язюк. Луиьк: ІВВ Луцького НТУ, 2020. 348 с.

виробництва, світової торгівлі, співвідношенню сил у світі. Криза світової валютної системи веде до зламу старої системи і іiі заміни нової, що забезпечує відносну валютну стабілізацію[2].

У зарубіжній літературі використовується вузьке визначення валютної кризи як значне знецінення валюти. Так, Дж. Френкел і А. Роуз визначили валютну кризу як номінальне знецінення валюти на $25 \%$ і більше при одночасному прискоренні темпу знецінення валюти на $10 \%$ і більше в річному виражені [3]. Б. Айхенгрін включають в поняття валютна криза значне знецінення валюти в результаті спекулятивної атаки [4].

Еволюція економічної природи валютних криз показала, що під час золотомонетного стандарту в індустріально розвинених країнах вони відбувалися іноді, в основному, у воєнний час i були результатом неадекватної політики влади i банківських криз, в той час як в країнах, що розвиваються валютні кризи траплялися набагато частіше із- за зміни уряду i як дія спекулятивна атака на валюту. У період між двома світовими війнами валютні кризи були наслідком загальних економічних шоків і представляли собою подвійні кризи. При Бреттон-Вудської валютної системи валютні кризи стали самостійною проблемою, яка породжувала інші кризи, в тому числі на фондовому ринку. Валютні паритеті були об'єктом спекулятивних атак, що приводило к необхідності отримання зовнішніх займав. Валютні паритеті були об'єктом спекулятивних атак, що призводило до необхідності отримання зовнішніх позик.

При Ямайської валютної системі після скасування валютних обмежень зросла міжнародна мобільність капіталу, яка стала рушійною силою валютних криз. Особливий вплив стали надавати процеси глобалізації і відкрився доступ до світових ринків капіталу. Скасування золотого забезпечення долара США дозволили значно збільшити грошову пропозицію. Зросла роль кредитних ресурсів і залежність економік країн від позикових коштів. Американські «гарячі гроші» стали 
Економічні науки: збірник наукових прачь Луиького національного технічного університету. Серія "Регіональна економіка". Випуск 17 (67). Редкол.: відп. ред. к.е.н., професор І.В. Кривов'язюк. Луиьк: ІВВ Луцького НТУ, 2020. 348 с.

перетікати з одного валютного ринку на інший, приводячи до валютних криз.

Переходячи до аналізу валютних криз в XXI столітті, важливо підкреслити, що в 2008 р валютна криза проявився як подвійний криза. Валютна криза протікав одночасно 3 кризою ліквідності в поєднанні з проблемами банківської системи. Він став частиною світової фінансової кризи і виявив нове в природі кризових явищ. Криза поширилась на весь світ (до цього кризи зачіпали окремі регіони) і протікала в умовах сильної взаємозалежності фінансового та реального секторів. Якщо раніше фінансова сфера носила підлеглий характер по відношенню до реального сектору, то в XXI столітті стали домінувати фінанси. Багаторазово підвищилася ймовірність утворення фінансових бульбашок.

Таким чином, валютна криза як одна 3 форм прояву фінансової кризи є складне і багатогранне явище. Валютні кризи останніх років змінили уявлення, як про природу кризових явищ, так і про їх наслідки. Переплетення з валютними кризами криз ліквідності, банківських i боргових криз, вплив глобалізації, посилення міжнародного перетікання капіталів, ускладнення структури фінансових ринків призводить до необхідності переосмислити економічну природу валютної кризи.

На сучасному етапі розвитку економіки природа валютних криз визначається наступним: валюта стала самостійним активом для інвестування вільних коштів, при цьому об'єктивною основою курсоутворення є процес відтворення i міжнародний обмін товарами i послугами; посилення взаємозв'язку реального і фінансового секторів при переважній ролі останнього; широке поширення фіктивного фінансового капіталу; значний масштаб і швидкість перетікання капіталу 3 одного валютного ринку на інший; ускладнення фінансових продуктів; спекуляції і прагнення ринкових гравців отримати надприбуток; обмеженість державного регулювання; різко зросла ступінь інтеграції різних країн у світову економіку.

Таким чином валютні кризи класифікуються: 
Економічні науки: збірник наукових прачь Луиького національного технічного університету. Серія "Регіональна економіка". Випуск 17 (67). Редкол.: відп. ред. к.е.н., професор І.В. Кривов’язюк. Луиьк: ІВВ Луцького НТУ, 2020. 348 с.

- криза національної валюти окремої країни, що виявляється через іії різке знецінення,

- криза єдиної валюти як штучного утворення, заснованого на угоді країн-учасниць валютного союзу,

- криза світової резервної валюти як основи сучасної світової валютної системи.

Криза національної валюти виражається в різкому значному знеціненні (девальвації) національної валюти за досить короткий період часу (від декількох днів до декількох місяців) після періоду відносної стабільності валютного курсу.

Криза єдиної валюти як штучного утворення, заснованого на угоді країн-учасниць валютного союзу, виникає в результаті невисокого ступеня економічної інтеграції і протиріч при проведенні єдиної грошово-кредитної і бюджетно-податкової політики для країн, що розрізняються станом державних фінансів, призводить до відмови від використання єдиної валюти і розпаду валютного союзу.

Криза світової резервної валюти є криза основ чинної світової валютної системи, що приводить до переосмислення і розробки принципів нової світової валютної системи, яка триває протягом тривалого періоду часу в зв'язку 3 необхідністю узгодження і підтримки більшістю провідних світових держав, відбувається в результаті ускладнення фінансових і економічних процесів і зміни розстановки сил у світовій економіці.

Висновки. В українських i закордонних наукових дослідженнях відсутній єдиний підхід до трактування поняття «валютна криза». Валютна криза одна з форм прояву фінансової кризи є складне і багатогранне явище.

\section{Список бібліографічного опису}

1.Аникин А.В. О типологии финансовых кризисов. Вестник Московского Университета. Серия 6. Экономика. 2001. № 4. с. 43-54 . с. 48.

2.Международные валютно-кредитные и финансовые отношения / Под ред. Л.Н.Красавиной. 3-е изд., перераб. и доп. М.: Финансы и статистика, 2005. 576 c. c. $56-57$.

3.Jeffrey A. Frankel, Andrew K. Rose Currency crashes in emerging markets: empirical indicators // NBER Working paper 5437. January 1996.

4.Eichengreen Barry, Andrew Rose and Charles Wyplosz Exchange Market 
Економічні науки: збірник наукових прачь Луиького національного технічного університету. Серія "Регіональна економіка". Випуск 17 (67). Редкол.: відп. ред. к.е.н., професор І.В. Кривов’язюк. Луцьк: ІВВ Луцького НТУ, 2020. 348 с.

Mayem: The Antecedents and Aftermath of Speculative Attacks // Economic Policy. 1995. Vol. 10. No. 21. Oct. PP. 249-312.

\section{References}

1. Anikin A.V. About the typology of financial crises - Bulletin of Moscow University. Series 6, Economics, 2001, no. 4, pp. 43-54.

2. Krasavina L.N. International monetary and financial relations. 3rd ed., rev. and add., Moskow, Finance and statistics, 2005. 576 p., pp. 56-57.

5.Jeffrey A. Frankel, Andrew K. Rose Currency crashes in emerging markets: empirical indicators // NBER Working paper 5437. January 1996.

6.Eichengreen Barry, Andrew Rose and Charles Wyplosz Exchange Market Mayem: The Antecedents and Aftermath of Speculative Attacks // Economic Policy. 1995. Vol. 10. No. 21. Oct. PP. 249-312. 